\title{
Prediksi Harga Kontrak Opsi Asia dalam Perdagangan Pasar Saham dengan Menggunakan Metode Monte Carlo
}

\author{
Rahmat Syam ${ }^{1}$, Ahmad Zaki ${ }^{1}$, dan Muhammad Hasriyadi Basri ${ }^{1, a)}$ \\ ${ }^{1}$ Jurusan Matematika, FMIPA, Universitas Negeri Makassar, 90224 \\ ${ }^{a}$ adhy.mhb@gmail.com
}

\begin{abstract}
Abstrak: Opsi adalah suatu kontrak yang memberikan hak (bukan kewajiban) kepada pemegang kontrak (option buyer) untuk membeli atau menjual suatu aset tertentu suatu perusahaan kepada penulis opsi (option writer). Apabila pada saat jatuh tempo (expiration date) pemegang opsi tidak menggunakan haknya, maka hak tersebut akan hilang dengan sendirinya. Dengan demikian opsi yang dimiliki tidak akan mempunyai nilai lagi. Monte Carlo adalah suatu metode yang menghendaki model simulasi yang mengikutsertakan bilangan acak dan sampel yang berbasis pada komputer. Prosedur simulasi melibatkan pembangkit bilangan acak dengan memberikan kepadatan probabilitas dan menggunakan hukum bilangan besar untuk mendapatkan rata-rata dari nilainya sebagai penaksir dari nilai harapan variabel acak. Penelitian ini bertujuan untuk memprediksi harga opsi saham pada periode kedepannya dan sebagai bahan pertimbangan bagi pelaku perdagangan saham untuk mengambul keputusan untuk menjual atau membali opsi suatu saham dengan menggunakan software Matlab. Jenis penelitian yang digunakan adalah penelitian terapan menggunakan metode Monte Carlo untuk mensimulasikan data saham. Hasil menunjukkan bahwa semakin banyak iterasi yang dilakukan maka nilai prediksi juga semakin baik dan konvergen ke suatu nilai. Nilai prediksi stabil pada iterasi ke-60000 dengan nilai error dari MAPE kurang dari $20 \%$ sehingga nilai prediksi dapat dikatakan baik.
\end{abstract}

Kata Kunci: Opsi Asia, Monte Carlo, Black-Scholes, Matlab, MAPE.

\begin{abstract}
Option is a contract that gives rights (not obligations) to the contract holder (option buyer) to buy or sell a certain asset of a company to the option writer (option writer). Monte Carlo is a method that requires a simulation model that includes random numbers and samples based on computers. The simulation procedure involves generating random numbers by providing a probability density and using the law of large numbers to get the average of its values as an estimator of the expected value of the random variable. This study aims to predict stock option prices in the future and as a material consideration for stock trading players to make a decision to sell or buy options for a stock using Matlab software. The type of research used is applied research using the Monte Carlo method to simulate stock data. The results show that the more iterations are carried out, the predictive value is also getting better and converging to a value. The predictive value is stable at the 60000th iteration with an error value of MAPE of less than $20 \%$ so that the predicted value can be said to be good.

Keywords: Asia Option, Monte Carlo, Black-Scholes, Matlab, MAPE.
\end{abstract}

\section{PENDAHULUAN}

Saham adalah tanda penyertaan atau kepemilikan seseorang atau badan dalam suatu perusahaan atau perseroan terbatas (Jogiyanto, 2013). Wujud dari saham itu sendiri adalah selembar kertas yang menerangkan pemilik kertas tersebut adalah pemilik perusahaan yang menerbitkan saham. Dalam saham, investor dapat memilih sekuritas yang mewakili saham yang disebut dengan opsi. 
Opsi adalah suatu kontrak yang memberikan hak (bukan kewajiban) kepada pemegang kontrak (option buyer) untuk membeli atau menjual suatu aset tertentu suatu perusahaan kepada penulis opsi (option writer). Apabila pada saat jatuh tempo (expiration date) pemegang opsi tidak menggunakan haknya, maka hak tersebut akan hilang dengan sendirinya. Dengan demikian opsi yang dimiliki tidak akan mempunyai nilai lagi (Halim, 2003). Opsi terbagi atas tiga tipe berdasarkan periode penggunaan waktunya, yaitu opsi Eropa, opsi Amerika, dan opsi Asia.

Opsi Asia adalah opsi yang payoff atau hasilnya tergantung pada rata-rata harga asset dasar selama periode yang telah ditentukan terlebih dahulu (Seydel, 2002). Opsi Asia merupakan gabungan dari opsi Amerika dan Eropa. Dimana opsi Asia dapat berlaku seperti opsi Eropa atau opsi Amerika. Hal yang membedakan opsi Asia dengan opsi Eropa dan opsi Amerika adalah harga pada saat pelaksanaan opsi. Harga saham yang digunakan sebagai acuan dalam opsi Asia adalah rata-rata harga saham pada waktu T. Opsi Asia lebih cenderung pada opsi Eropa karena pelaksanaan opsi tersebut pada waktu T. Untuk mengetahui harga saham maka dibutuhkan suatu simulasi yang nantinya akan menghasilkan harga prediksi.

Menurut Kakiay (2004) simulasi adalah suatu sistem yang digunakan untuk memecahkan atau menguraikan persoalan-persoalan dalam kehidupan nyata yang penuh dengan ketidakpastian dengan tidak atau menggunakan model atau metode tertentu dan lebih ditekankan pada pemakaian komputer untuk mendapatkan solusinya. Salah satu yang banyak berperan dalam simulasi komputer adalah metode Monte Carlo. Metode ini memiliki kemampuan untuk membentuk logika seperti operasi matematika dalam suatu model, dan juga dapat mengikuti suatu model untuk kemudian dikembangkan pelaksanaanya dalam komputer.

Kwot (2000) menyatakan bahwa metode Monte Carlo pada dasarnya suatu prosedur numerik untuk menaksir nilai harapan dari variabel acak, dengan menaksir dirinya sendiri untuk menentukan nilai harapan. Prosedur simulasi melibatkan pembangkit bilangan acak dengan memberikan kepadatan probabilitas dan menggunakan hukum bilangan besar untuk mendapatkan rata-rata dari nilainya sebagai penaksir dari nilai harapan variabel acak. Simulasi Monte Carlo menggunakan model stokastik memperoleh hasil yang lebih baik untuk eksperimen yang aktual dalam penelitian di dunia nyata.

Beberapa penelitian sebelumnya yang telah menggunakan metode Monte Carlo (Fatimah, 2016; Haryono, 2009; Lessy, 2013; Mahayoga, dkk, 2014; Mardiansyah, 2013; Tupan, dkk, 2013; Uyanto, 2007). Mahayoga, Dharmawan, dan Harini (2014) menggunakan metode Monte Carlo untuk mengetahui hasil simulasi harga saham dalam menentukan harga opsi call dan kemudian dibandingkan dengan hasil simulasi dari metode Quasi Monte Carlo. Uyanto (2007) menggunakan metode Quasi Monte Carlo untuk dibandingkan dengan barisan acak Halton dan Sobol dalam option pricing. Dalam penelitian ini ditunjukkan bahwa metode Quasi Monte Carlo dengan barisan kuasi acak Sobol memberikan hasil terbaik, hal ini terlihat dari residual untuk European Call Options dan European Put Options yang selalu jauh lebih kecil dibandingkan dengan metode Monte Carlo dan Quasi Monte Carlo dengan barisan acak Halton.

Oleh karena itu dalam penelitian ini digunakan metode Monte Carlo untuk menentukan prediksi harga saham tipe Asia. Dalam penelitian ini juga digunakan model saham Black-Scholes untuk membangkitkan harga saham yang akan menjadi patokan nilai harga saham standar. Setelah harga saham dibangkitkan selanjutnya akan ditentukan prediksi nilai jual dan beli dengan cara melakukan iterasi sebanyak mungkin, iterasi akan berhenti jika nilai dinyatakan konvergen ke suatu nilai. Hasil dari simulasi Monte Carlo ini menjadi nilai prediksi harga saham tipe Asia.

\section{METODE PENELITIAN}

Jenis penelitian yang dilakukan adalah penelitian terapan yang mensimulasikan data saham yang didapat dan menaksir harga opsi yang sesuai. Data yang digunakan adalah data pergerakan saham perusahaan mulai dari Januari 2015 sampai dengan Oktober 2018. Data yang telah 
diambil kemudian dianalisis dengan menghilangkan nilai outlier (bernilai nol) agar dalam proses prediksi nantinya tidak ditemukan kerugian.

Setelah data diolah dengan menghilangkan data yang outlier, selanjutnya dihitung rata-rata harga saham dengan persamaan (1)

$$
\bar{S}=\frac{1}{M} \sum_{i=1}^{M} S_{i}
$$

dan untuk menghitung standar deviasinya seperti pada persamaan (2)

$$
\sigma^{2}=\operatorname{Var}(S)
$$

Parameter tersebut akan menjadi patokan dalam membangkitkan harga pada langkah berikutnya. Dari parameter yang telah diperoleh dapat ditentukan pula bunga yang akan diasumsikan pada harga saham yang akan dibangkitkan dengan persamaan (3)

$$
r=\left(\bar{S}-\frac{\sigma^{2}}{2}\right)
$$

Proses membangkitkan harga saham melibatkan proses stokastik dimana harga saham pada waktu $t+1$ dipengaruhi oleh harga saham pada waktu $t$. Untuk membangkitkan harga saham digunakan model harga saham Black-Scholes (Higham,2004), seperti pada persamaan (4).

$$
S_{i+t}=S_{i} e^{\left(\mu-\frac{1}{2} \sigma^{2}\right)\left(t_{i+1}-t_{i}\right)+\sigma \sqrt{t_{i+1}-t_{i} \zeta_{i}}}
$$

Harga saham bangkitan sangat bergantung pada waktu, karena dalam membangkitkan harga saham melibatkan bilangan acak yang stokastik. Dalam hal ini bilangan acak stokastik terdistribusi normal dengan rata-rata 0 dan standar deviasi 1 . Harga saham dibangkitkan dalam 1 hari meliputi 10 kemungkinan harga yang terjadi kemudian diambil rata-ratanya. Rata-rata harga saham yang terjadi tersebut menjadi harga saham penutupan pada hari itu.

Hal-hal yang harus ditentukan dalam penelitian ini diantaranya adalah:

- Exercise price, terdapat dua macam exercise price yaitu untuk opsi beli dan opsi jual.

- Bunga yang terjadi pada saat itu, dalam hal ini ditentukan oleh laju pertumbuhan harga saham data real dengan mengambil rata-rata dan standar deviasinya, dan diasumsikan bunga tetap selama $\mathrm{N}$ hari.

- Waktu jatuh tempo (T) sesuai dengan banyaknya harga saham yang dibangkitkan, dan

- Harga saham terakhir, dimana dalam opsi merupakan rata-rata harga saham yang terjadi selama $66(\mathrm{~T})$ hari.

Nilai keuntungan opsi beli Asia ditentukan berdasarkan nilai payoff yang didapat dari persamaan (5)

$$
\Lambda C(S(T))=\left(\bar{S}_{T}-E, 0\right)
$$

dan untuk menentukan harga jualnya sekarang digunakan persamaan (6)

$C=e^{-r(T-t)} \max \left(\bar{S}_{T}-E, 0\right)$

Hal ini dilakukan karena opsi akan dilaksanakan pada hari selanjutnya setelah terjadi kesepakatan. Keuntungan maksimum akan terjadi sebanyak selisih tersebut dan bernilai positif, namun jika nilai yang diperoleh negatif mana akan dinilai 0 karena pihak tersebut akan rugi jika meng exercise opsi tersebut.

Sedangkan untuk nilai keuntungan opsi jual Asia ditentukan berdasarkan nilai payoff yang didapat dari persamaan (7)

$$
\Lambda P(S(T))=\left(E-\bar{S}_{T}, 0\right)
$$

dan untuk menentukan harga jualnya sekarang digunakan persamaan (8)

$$
P=e^{-r(T-t)} \max \left(E-\bar{S}_{T}, 0\right)
$$

Keuntungan yang diperoleh pihak pembeli opsi jual adalan sebesar selisih dari exercise price dengan harga saham terakhir yang terjadi pada waktu itu. Nilai yang dihasilkan akan selalu 
positif karena jika nilai negatif maka nilai opsi menjadi 0 dan pihak pembeli opsi tidak mungkin meng exercise opsi tersebut karena pihak pembeli akan rugi.

$S_{T}$ dalam opsi Asia didefinisikan $\bar{S}_{T}=\sum_{i=1}^{N} \frac{S\left(t_{i}\right)}{N}$, untuk mendapatkan hasil yang baik simulasi Monte Carlo dari suatu sampel perlu dilakukan berulang-ulang.

Setiap satu simulasi akan mencakup 2 langkah sebelumnya yaitu membangkitkan harga saham dan menetukan nilai opsi saham, dimana dalam setiap simulasi mengulang kedua proses tersebut sebanyak iterasi yang dijalankan. Setelah melakukan simulasi Monte Carlo dan melakukan iterasi yang cukup besar, nilai yang diharapkan opsi diperoleh dengan menghitung rata-rata dari penaksir nilai yang dihasilkan, misalkan $C_{i}$ menyatakan penaksir dari nilai opsi beli yang diperoleh dalam simulasi dan $\mathrm{M}$ adalah jumlah angka pada simulasi yang dijalankan. Nilai opsi beli yang diharapkan diberikan oleh persamaan (9)

$$
\hat{C}=\frac{1}{M} \sum_{i=1}^{M}\left(C_{i}\right.
$$

dan ragam dari penaksir dihitung dengan persamaan (10)

$$
\hat{\sigma}^{2}=\frac{1}{M-1} \sum_{i=1}^{M}\left(C_{i}-C\right)^{2}
$$

Semakin banyak nilai $M$ yang dimasukkan, maka nilai opsi jual dan opsi beli akan stabil pada satu nilai, jika hal itu terjasi makan iterasi dihentikan.

\section{HASIL DAN PEMBAHASAN}

Analisis data pergerakan harga saham dalam bentuk grafik dapat dilihat pada Gambar 1.

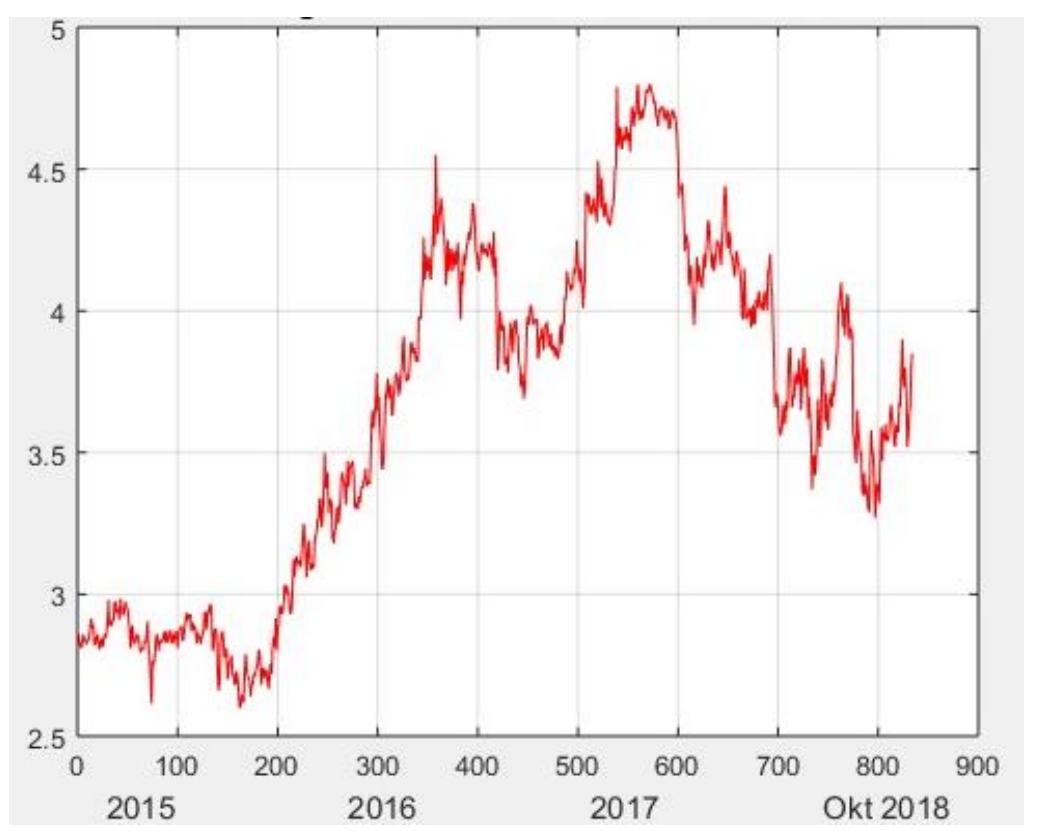

GAMBAR 1. Grafik Pergerakan harga saham selama 4.10 tahun terakhir

Gambar 1 merupakan pergerakan harga saham yang digunakan sebagai sampel untuk membangkitkan harga saham pada waktu selanjutnya dengan menggunakan parameter dari data real tersebut. Harga saham tersebut yang digunakan sebagai sampel untuk membangkitkan harga saham pada waktu selanjutnya dengan menggunakan parameter dari data real tersebut. Grafik diatas dalam bentuk per ribuan sehingga pergerakan harga saham dalam bentuk ribuan. Perilaku yang tampak pada grafik menunjukkan pergerakan harga saham yang normal dalam arti antara harga saham sekarang dengan besok jangkauannya tidak terlalu tinggi. Banyaknya data yang digunakan sebanyak 834 harga saham, berdasarkan persamaan (1) diperoleh bahwa $\bar{S}$ 
$=$ Rp. 3655,647 dan diperoleh standar deviasi harga saham real berdasarkan persamaan (2) yaitu $\sigma^{2}=$ Rp. 603,54 , paremeter tersebut akan menjadi patokan dalam membangkitkan harga pada langkah berikutnya.

Dari parameter yang telah diperoleh dapat ditentukan pula bunga yang akan diasumsikan pada harga saham yang akan dibangkitkan, yaitu

$$
r=\left(\bar{S}-\frac{\sigma^{2}}{2}\right)=\left(3655,6-\frac{603,5}{2}\right)=3,4735 .
$$

Dalam proses simulasi Monte Carlo, ada 2 langkah yaitu membangkitkan harga saham dan menentikan nilai opsi saham. Membangkitkan harga saham dihitung dengan persamaan (4), sehingga diperoleh:

$$
\begin{aligned}
S b & =S_{0} e^{\left(-\frac{r}{N}\right) T+\sigma^{2} \sqrt{T}} \\
& =3,8500 \times e^{\left(-\frac{3,4735}{66}\right)(0,0152)+(0,6035)(0,1233)} \\
& =3,8500 \times 1,0764=4,1441
\end{aligned}
$$

Nilai harga saham yang diperoleh kemudian dibangkitkan dengan 10 bilangan acak. Maka dari itu digunakan software Matlab untuk membantu dalam memperoleh hasilnya dan dirata-ratakan, proses ini dilakukan sebanyak 66 kali sesuai dengan waktu jatuh tempo yang diberlakukan, nilai rata-rata dari 66 nilai tersebut disimbolkan sebagai $\bar{S}_{T}$.

Selanjutnya masukkan jumlah iterasi sebanyak M, proses iterasi dari opsi beli $(C)$ dan opsi beli $(P)$ akan terus berulang sebanyak $M$ yang diinginkan. Untuk opsi beli dapat diperoleh:

$$
\begin{aligned}
C & =e^{-r(T-t)} \max \left(\bar{S}_{T}-E, 0\right) \\
& =e^{(-3,4753 \times 0.0152)} \max (3,8678-3,052,0) \\
& =e^{(-0,0528)} \max (0,8157,0) \\
& =0,77377 \text { (dalam ribuan) }=\mathrm{Rp} .773,77
\end{aligned}
$$

dengan exercise pricenya yaitu Rp. 3052,1, hasil tersebut didapatkan dari selisih nilai rata-rata saham dengan standar deviasinya. Kemudian untuk nilai opsi jualnya diperoleh:

$$
\begin{aligned}
P & =e^{-r(T-t)} \max \left(E-\bar{S}_{T}, 0\right) \\
& =e^{(-3,4753 \times 0.0152)} \max (4,2592-3,8678,0) \\
& =e^{(-0,0528)} \max (0,3914,0) \\
& =0,37127 \text { (dalam ribuan) }=\mathrm{Rp} .371,27
\end{aligned}
$$

dengan exercise pricenya adalah Rp. 4259,2, hasil tersebut didapatkan dari jumlah nilai rata-rata saham dengan standar deviasinya. Nilai tersebut adalah nilai prediksi opsi Asia pada iterasi pertama. Kemudian proses tersebut akan berulang sesuai nilai $\mathrm{M}$ dan hasilnya akan dirataratakan. Hasil opsi jual dan opsi beli dari setiap iterasi yang dilakukan disajikan dalam Tabel 1.

Dari Tabel 1 hasil simulasi tampak perubahan yang diperoleh pada interval nilai opsi jual dan beli yang diperoleh dimana semakin banyak simulasi yang dilakukan maka semakin mengerucut jarak selang yang diperoleh, dalam arti akan menuju ke suatu nilai. Seperti tampak pada hasil simulasi yang ketujuh $(\mathrm{M}=60000)$ dan kedelapan $(\mathrm{M}=65000)$ didapatkan nilai rata-rata sebesar Rp.381,01 dan Rp.764,18. Hal ini menunjukka bahwa perubahan jumlah pada $M=60000$ dan seterusnya didapatan nilai rata-rata yang konvergen.

Berdasarkan Gambar 1 menunjukkan bahwa nilai yang bergerak pada setiap simulasi yang dilakukan mendekati suatu nilai tertentu. Simulasi no.1 merupakan iterasi 10 kali dan seterusnya berdasarkan tabel hasil simulasi. Tampak pada simulasi no.7 dan no.8 nilai yang diperoleh sama, sehingga garis yang menghubungkan nilai simulasi no.7 dan simulasi no.8 berupa garis lurus. Berdasarkan hukum bilangan besar maka dari hasil yang diperoleh diatas dapat dikatakan bahwa banyaknya rata-rata sampel sesuai dengan banyaknya simulasi yang dilakukan dan rata- 
rata yang konvergen pada nilai tengah akan selalu berlaku meskipun banyaknya simulasi ditambah menuju tak hingga. Dengan demikian hukum nilangan besar merupakan penduga dari rata-rata populasi yang jumlahnya sangat besar, dalam arti parameter yang dihasilkan merupakan penduga dari raata-rata.

TABEL 1. Hasil Simulasi

\begin{tabular}{|c|c|c|c|}
\hline No. & Banyak M & $\begin{array}{l}\text { Rata-rata Nilai Opsi } \\
\text { Jual (ribuan) }\end{array}$ & $\begin{array}{c}\text { Rata-rata Nilai Ops } \\
\text { Beli (ribuan) }\end{array}$ \\
\hline 1 & 10 & 384,54 & 760,64 \\
\hline 2 & 100 & 380,94 & 764,26 \\
\hline 3 & 1000 & 381,08 & 764,11 \\
\hline 4 & 5000 & 380,83 & 764,37 \\
\hline 5 & 10000 & 380,89 & 764,31 \\
\hline 6 & 50000 & 381,00 & 764,20 \\
\hline 7 & 60000 & 381,01 & 764,18 \\
\hline 8 & 65000 & 381,01 & 764,18 \\
\hline 9 & 70000 & 381,02 & 764,18 \\
\hline 10 & 80000 & 380,99 & 764,20 \\
\hline 11 & 90000 & 380,98 & 764,22 \\
\hline 12 & 100000 & 380,97 & 764,22 \\
\hline
\end{tabular}

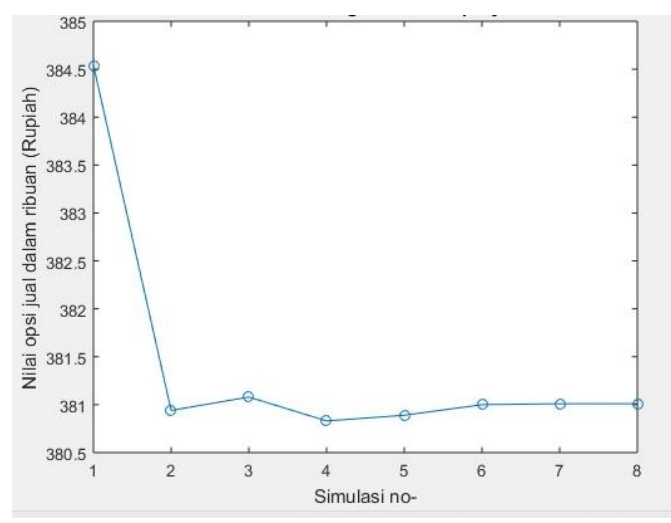

(a) Grafik kekonvergenan nilai opsi jual

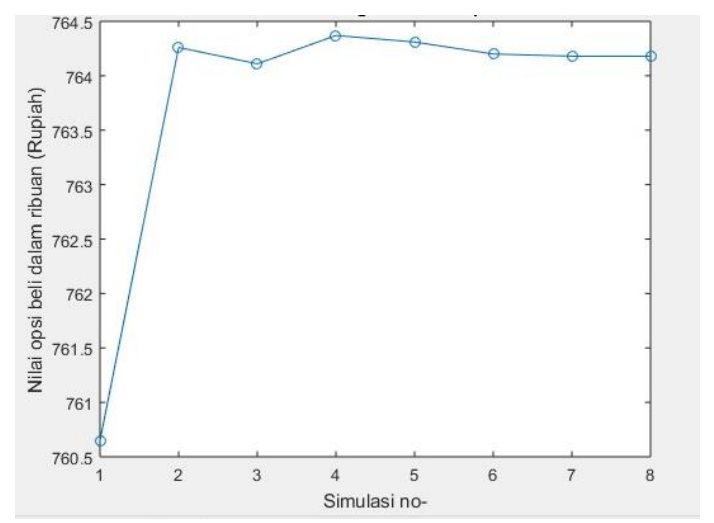

(b) Grafik kekonvergenan nilai opsi beli

GAMBAR 1. Grafik kekonvergenan

\section{KESIMPULAN}

Simulasi Monte Carlo dapat memprediksi harga saham dan menentukan nilai kontrak opsi tipe Asia. Data saham yang telah didapatkan selanjutnya dicari parameter data real harga saham yang akan menjadi patokan membangkitkan harga saham yang melibatkan proses stokastik menggunakan model harga saham Black-Scholes. Ditentukan exercise price, bunga yang terjadi pada saat tersebut, waktu jatuh tempo berdasarkan banyaknya harga saham yang dibangkitkan, dan harga saham terakhir. Opsi tipe Asia merupakan rata-rata harga saham yang terjadi selama 66 hari. Kemudian data saham diproses dengan simulasi Monte Carlo yang diiterasi untuk menghasilkan nilai yang menunjukkan kekonvergenan pada suatu nilai.

Hasil estimasi harga kontrak tipe Asia menunjukkan bahwa semakin banyak iterasi maka estimasi nilai rata-rata opsi yang diperoleh semakin konvergen. Pada opsi jual simulasi 
menghasilkan nilai yang konvergen pada Rp.381,01 dengan standar deviasi 10,6, sedangkan pada opsi beli simulasi menghasilkan nilai yang konvergen pada Rp.764,18 dengan standar deviasi 10,6. Kedua nilai opsi tersebut diperoleh pada saat iterasi ke-60000.

Pada skripsi ini penulis hanya memfokuskan pada hasil simulasi Monte Carlo standar dalam menentukan nilai opsi saham. Maka diharapkan pada skripsi selanjutnya untuk mengkaji simulasi Monte Carlo lebih dalam lagi dengan mereduksi standar deviasi atau mengembangkan nilai eksak dari model Black-Scholes untuk opsi Asia. Atau dengan menggunakan metode lain seperti Quasi Monte Carlo, Control Variate, dan lain-lain.

\section{REFERENSI}

Fatimah, U.N. (2016). Pengukuran Value at Risk pada Portofolio dengn Menggunakan Model Simulasi Monte Carlo (Skripsi). Universitas Negeri Semarang, Semarang.

Halim, A. (2003). Analisis Investasi. Jakarta: Edisi Kedua. Salemba Empat.

Haryono, N. A. (2009). Perhitungan Integral Lipat menggunakan Metode Monte Carlo. Jurnal Informatika, Volume 5(2). 70-77.

Higham \& Desmond J. (2004). Black-Scholes Option Valuatio for Scientific Computing Students. Scotland; Depart. Of Mathematics, University of Strathclyde.

Jogiyanto. (2003). Teori Portofolio dan Analisis Investasi. Yogyakarta: BPFE.

Kakiay \& Thomas J. (2004). Pengantar Sistem Simulasi. Yogyakarta: ANDI Yogyakarta.

Kwok \& Kuen Y. (2000). Mathematical Models of Financial Derivatives. Tokyo: Springer.

Lessy, D. (2013). Simulasi Monte Carlo dalam Penetuan Harga Opsi Barrier. Jurnal Matematika dan pembelajarannya, Volume 2(2). 20-28.

Mahayoga, G. P. N., Dharmawan, K., Harini, L. P. I. (2013). Penentuan Harga Kontrak Opsi Tope Eropa Menggunakan Metode Quasi Monte Carlo dengan Barisan Kuasi Acak Halton. E-Jurnal Matematika, Volume 3(4). 154-159.

Mardiansyah, D. (2013). Analisa Sifat Ferromagnetik Material Menggunakan Metode Monte Carlo. Jurnal Ilmiah Edu Research, Volume 2(2). 65-74.

Seydel, U.R. (2002). Tools for Computational Finance. Koln: Springer.

Tupan, P. T., Manurung, T., Prang, J. D. (2013). Pengukuran Value at Risk pada Aset Perusahaan dengan Metode Simulasi Monte Carlo. Jurnal MIPA UNSRAT Online, Volume 2(1). 5-11.

Uyanto, S. S. (2007). Perbandingan Metode Quasi Monte Carlo dengan Barisan Kuasi Acak Halton dan Barisan Kuasi Acak Sobol dalam Option Pricing. Majalah Ekonomi dan Komputer. No. 1 Tahun XV-2007. 